$12-2002$

\title{
Epibiotic Sponges on the Scallops Chlamys Hastata and Chlamys Rubida: Increased Survival in a High- Sediment Environment
}

\author{
Duncan O. Burns \\ Western Washington University \\ Brian L. Bingham \\ Western Washington University, brian.bingham@wwu.edu
}

Follow this and additional works at: https://cedar.wwu.edu/esci_facpubs

Part of the Environmental Sciences Commons

\section{Recommended Citation}

Burns, Duncan O. and Bingham, Brian L., "Epibiotic Sponges on the Scallops Chlamys Hastata and Chlamys Rubida: Increased Survival in a High-Sediment Environment" (2002). Environmental Sciences Faculty and Staff Publications. 1.

https://cedar.wwu.edu/esci_facpubs/1 


\title{
Epibiotic sponges on the scallops Chlamys hastata and Chlamys rubida: increased survival in a high-sediment environment
}

\author{
Duncan O. Burns $*^{\ddagger}$ and Brian L. Bingham ${ }^{\dagger}$ \\ *Department of Biology, Western Washington University, Bellingham, WA 98225, USA. ${ }^{\dagger}$ Department of Environmental Sciences, \\ Western Washington University, Bellingham, WA 98225, USA. ${ }^{\ddagger}$ Corresponding author, 1125 13th Street, Bellingham, WA 98229 \\ e-mail: dburns5@ibius.jnj.com
}

The small free-swimming scallops, Chlamys hastata and Chlamys rubida, are frequently encrusted by the sponges Mycale adhaerens and Myxilla incrustans. It is unclear why this association exists. We hypothesized that living on scallop valves increases sponge survival by reducing the effects of sediment accumulation. Scallops were collected to measure correlations between sediment load and encrusting sponge mass. In the laboratory, the survival of sponges on living scallops and empty scallop valves was measured. Time-lapse video was used to quantify spontaneous swimming and clapping of C. hastata. In the field, both scallop size and sponge mass were significantly greater in high turbidity sites. In the laboratory, sponges on empty scallop valves experienced near complete mortality after five weeks. Manually clearing sediments increased survival but did not duplicate the high survival of sponges on living scallops, which regularly swam or clapped their valves.

\section{INTRODUCTION}

Epibiotic invertebrates encrust the valves of scallops around the world (e.g. Forester, 1979; Chernoff, 1987; Ward \& Thorpe, 1991; Berkman, 1994). The selective forces driving these epifaunal associations are either unique to each association, or common threads have simply not yet been described.

The associations of the sponges Mycale adhaerens (Lambe) and Myxilla incrustans (Esper) with the scallops Chlamys hastata (Sowerby) and Chlamys rubida (Hinds) are a dominant feature of the benthic biota on hard substrates in the Puget Sound and San Juan Archipelago, Washington, USA. Currently, the most popular theory explaining these strong associations is that both scallops and sponges are better able to escape predators when they are living symbiotically.

In the laboratory, Bloom (1975) found that the predatory seastars Orthasterias koehleri and Evasterias troschelii had a harder time gripping, manipulating and capturing scallops that were covered by epibiotic sponge. He asserted that sponge-covered scallops could, therefore, more easily escape predation. Stimulated by these findings, researchers have applied the seastar predation model to other sponge/ scallop associations and obtained similar results (Forester, 1979; Chernoff 1987). Although these data seem to support seastar predation and the tube-foot interference mechanism as a reasonable explanation for the association, it is not clear that it alone explains the evolution and maintenance of the relationship.

The predation model assumes that sponge covering effectively deters seastar predators. However, the sponges covering $C$. hastata do not deter more aggressive species. Bloom (1975) found that Pycnopodia helianthoides, a common voracious predator, captured sponge-encrusted and unencrusted scallops with equal frequency. Furthermore, it is not clear that any species of seastar in the Puget Sound eats scallops as a significant part of its natural diet. Mauzey et al. (1968), in an extensive survey of seastars in the Puget Sound region, found only four of 18 species feeding on scallops in the field (scallops were seen in only six of nearly 3000 feeding observations). Two of six predation observations were the seastar Pteraster tesselatus, which actually feeds preferentially on M. adhaerens and Myxilla encrustans from the valves of scallops as well as on the scallops themselves (Rohenhous \& Guberlet, 1946). Clearly, epibiotic sponges could actually be a liability for scallops encountering this seastar.

It is possible that the greater benefit from the sponge/ scallop association accrues not to the scallop but to the sponge. Bloom (1975) observed in the laboratory that dorid nudibranchs were better able to feed on epibiotic sponges when their scallop hosts were prevented from swimming. He suggested that swimming by the scallops provides an escape for the sessile sponge, thus serving as a secondary selective force favouring the association.

While such predator escape may benefit the sponge, we hypothesized that a more likely benefit is an escape from heavy sediment deposition. Sponges are sensitive to high levels of suspended particles; many sponges are excluded from areas with heavy sediment loads (Bakus, 1967) since their canals and chambers can be easily clogged by sediment (Gerrodette \& Flechsig, 1979). Chernoff (1987) found that epibiotic sponges experienced greater siltation and abrasion when the host scallop was attached to the seabed.

Because of their flat morphology, Mycale adhaerens and Myxilla incrustans may be particularly vulnerable to sediments. In the Puget Sound, strong river input, heavy precipitation, regular algal blooms and strong tidal mixing all contribute to heavy particulate loads. We postulate that periodic swimming of the scallop increases the tolerance 
of the sponges for high sediment environments by preventing sediments from accumulating on their surfaces.

\section{MATERIALS AND METHODS}

\section{Field collections}

Scallops were collected from subtidal sites in the San Juan Archipelago, Washington, USA. Two sites (Pile Point and Eagle Point) were located on the exposed west side of San Juan Island. Two protected sites (Cone Islands and Cypress Reef, Figure 1) were also sampled. The west side of San Juan Island is influenced by clear waters of the open North Pacific Ocean and is known by SCUBA divers as an area of unusually good visibility. In contrast, the inshore sites of Rosario Strait and Bellingham Channel are heavily influenced by inflow of several large rivers, which contributes to nutrient loads, algal blooms and high turbidity.

At each study site, SCUBA divers collected 25 Chlamys hastata from depths of 18 and 24 metres. The scallops were taken to the Shannon Point Marine Center where they were identified to species. We measured height of each scallop (dorsal hinge to the furthest point on the ventral margin) and determined the species of encrusting sponges. We used a contingency table to test for site-related differences in distributions of the two epibiotic sponges. The factors were sponge species (Mycale adhaerens or Myxilla incrustans) and site (Eagle Point, Pile Point, Cone Island or Cypress Reef). Each scallop/sponge association was assigned to one cell in the table since only one sponge species was present on any scallop.

To quantify sponge cover, we calculated the surface area of each dorsal scallop valve (assuming the valve was a circle with a diameter equal to its height). The sponge was then scraped off, rinsed, dried in an oven at $90^{\circ} \mathrm{C}$ for $24 \mathrm{~h}$ and weighed. We divided the dry weight of each sponge by the surface area of the host scallop valve to yield a dry sponge biomass per $\mathrm{cm}^{2}$.

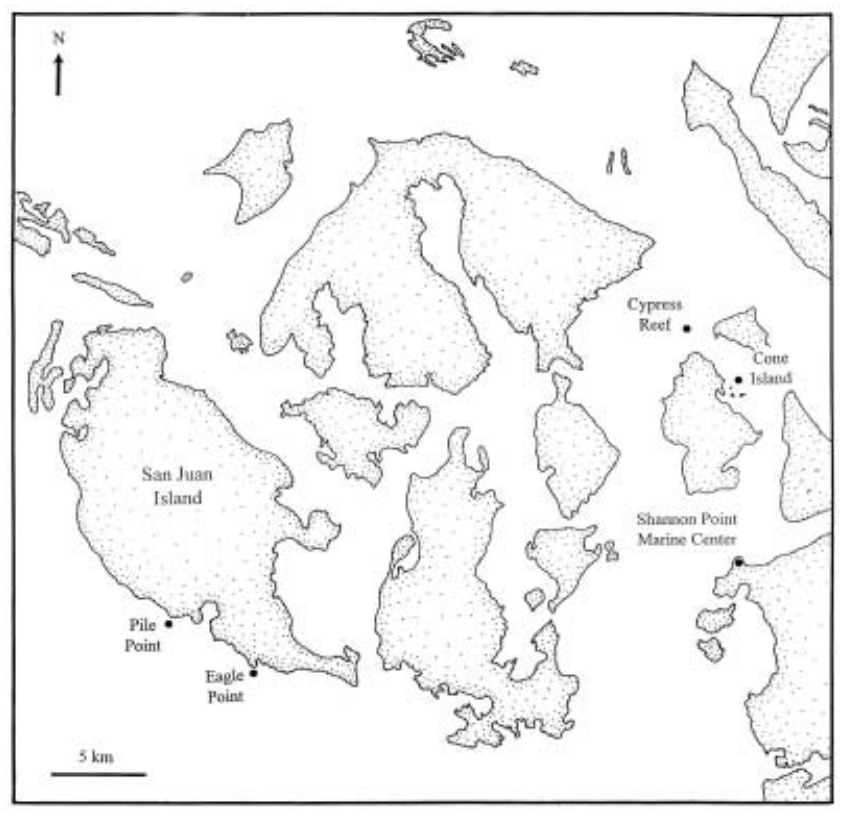

Figure 1. Study sites in the San Juan Archipelago, Washington, USA.
Two-way analysis of variance (ANOVA) was used, with site and depth as the main effects, to determine whether scallop size and sponge cover differed among locations. The sponge cover data were log transformed to homogenize variances. We used orthogonal contrasts to test for differences between exposed and inland sites (Eagle Point and Pile Point vs Cone Island and Cypress Reef) and between sites within each of these groups (Eagle Point vs Pile Point; Cone Island vs Cypress Reef).

We hypothesized that scallop size and sponge mass could be related to sedimentation. To estimate sediment loads, we deployed sediment collectors at all four locations. The collectors were PVC tubes $(5.0 \mathrm{~cm}$ inside diameter $\times 39 \mathrm{~cm}$ tall) capped on the bottom end. They were attached to lines weighted by cement blocks and held upright by floats. Three collectors were placed at $18 \mathrm{~m}$ and $24 \mathrm{~m}$ at each location. They were left in place for seven days (26 November3 December, 2001).

In the laboratory, we allowed the collected sediments to settle then transferred them to pre-weighed aluminium pans. The samples were dried at $60^{\circ} \mathrm{C}$ for $96 \mathrm{~h}$ then reweighed to determine dry sediment weight. We used 2way ANOVA to test for differences in sedimentation as a function of site and depth. Data were log-transformed to homogenize variances.

\section{Scallop behaviour}

In the laboratory, we observed C. hastata spontaneously clapping its valves or swimming around the tank. To determine how frequently these behaviours occur, we placed six sponge-encrusted C. hastata in a $50 \times 26 \times 30 \mathrm{~cm}$ glass aquarium supplied with fresh circulating seawater. A video camera was placed over the aquarium (illuminated by a single dim fluorescent bulb) and recorded the scallops for six hours.

\section{Sediment tolerance}

To explore the tolerance of epibiotic sponges for sediment deposition and the potential effects of scallop behaviour, we experimentally tested how swimming affects survival of sponges on $C$. hastata valves. We collected fresh, sponge-covered C. hastata from the Cone Island site and transported them to the Shannon Point Marine Center. The scallops were selected for uniformity in sponge thickness and for complete encrustation. A 1-cm diameter sample was removed from the centre of each sponge by making a circular cut with a plastic tube. The samples were rinsed with distilled water, dried at $60^{\circ} \mathrm{C}$ for $72 \mathrm{~h}$ and weighed. This was done to ensure that the scallops had similar amounts of sponge overgrowth at the commencement of the experiment. We also wished to have bare space in which we could measure sponge regrowth.

From the sponge-encrusted scallops, we prepared two groups. One group consisted of sponge-encrusted valves only, obtained by dissecting the scallops, removing the animal and the bottom valve, and leaving one valve with its attached sponge. The second group consisted of Mycale adhaerens growing on intact, living C. hastata. Eight of the empty valves and four living scallops were placed randomly in a rectangular seatable $(152 \times 70 \times 15 \mathrm{~cm})$ with a flowing seawater supply. 
For the following five weeks, the four living scallops received no treatment. They were simply allowed to reside within the flow-through seatable. Four of the empty valves were also left undisturbed in the bottom of the tank for the duration of the experiment. The remaining four empty valves rested in the bottom of the tank but their encrusting sponges were cleared of sediment every $24 \mathrm{~h}$ by gently blowing seawater across their surface with a large syringe. For comparison, an identical experiment was set up with $C$. hastata encrusted by the sponge Myxilla incrustans.

Our original intent was to measure sponge regrowth as an indicator of health. However, regrowth did not occur in any of the treatments. Instead, tissue necrosis occurred, to some degree, in most cases. To quantify sponge mortality, we photographed each sponge and used image analysis to measure the area of dead tissue (indicated by bare space or by grey sponge tissue). We used one-way ANOVA followed by Tukey's honestly significant difference (HSD) comparisons to test for differences in per cent necrosis among treatments for each species.

\section{RESULTS \\ Field collections}

Ninety-seven per cent of the scallops collected from the study sites were covered by epibiotic sponges. Mycale adhaerens was the most common epibiont at all sites. Myxilla incrustans was much less common but was still found at all sites and depths. Contingency table analysis failed to show any differences in relative abundances of the sponges at the sites $\left(\mathrm{X}_{0.05,3}^{2}=5.83, P=0.12\right.$; Figure 2$)$.

Analysis of variance showed no significant depth-related patterns of scallop size. However, there were differences among sites (Table 1). Orthogonal contrasts showed that scallops from protected sites (Cone Island and Cypress Reef) were significantly larger than those collected from exposed sites (Eagle Point and Pile Point, $P<0.01$; Figure 3 ). There were no differences between the two exposed sites $(P=0.84)$ or between the two sheltered sites $(P=0.81)$.

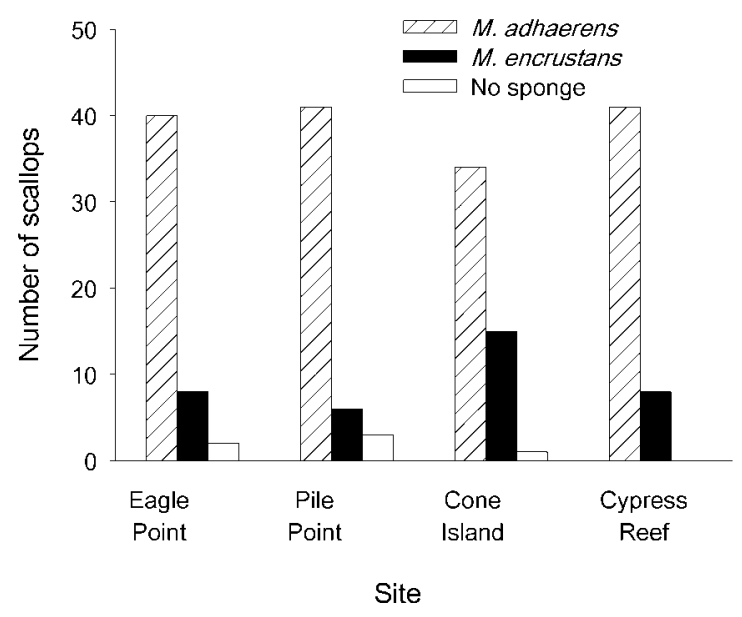

Figure 2. Epibiont growth on Chlamys hastata collected from four study sites. Two (Eagle Point and Pile Point) are on the exposed west side of San Juan Island. The other two (Cone Island and Cypress Reef) are in the more protected waters of the inner islands.
Table 1. Analysis of variance table for size of Chlamys hastata collected from four sites (Pile Point, Eagle Point, Cone Island and Rosario Strait) at 18 and $24 \mathrm{~m}$ depths.

\begin{tabular}{lrrrrr}
\hline Source & df & MS & $F$ & $P$ & Power \\
\hline Site & 3 & 2.07 & 5.84 & $<0.01$ & \\
Depth & 1 & 1.14 & 3.23 & 0.07 & 0.43 \\
Site $\times$ Depth & 3 & 0.31 & 0.89 & 0.44 & 0.24 \\
Error & 149 & 0.35 & & & \\
\hline Total & 156 & & & & \\
\hline
\end{tabular}
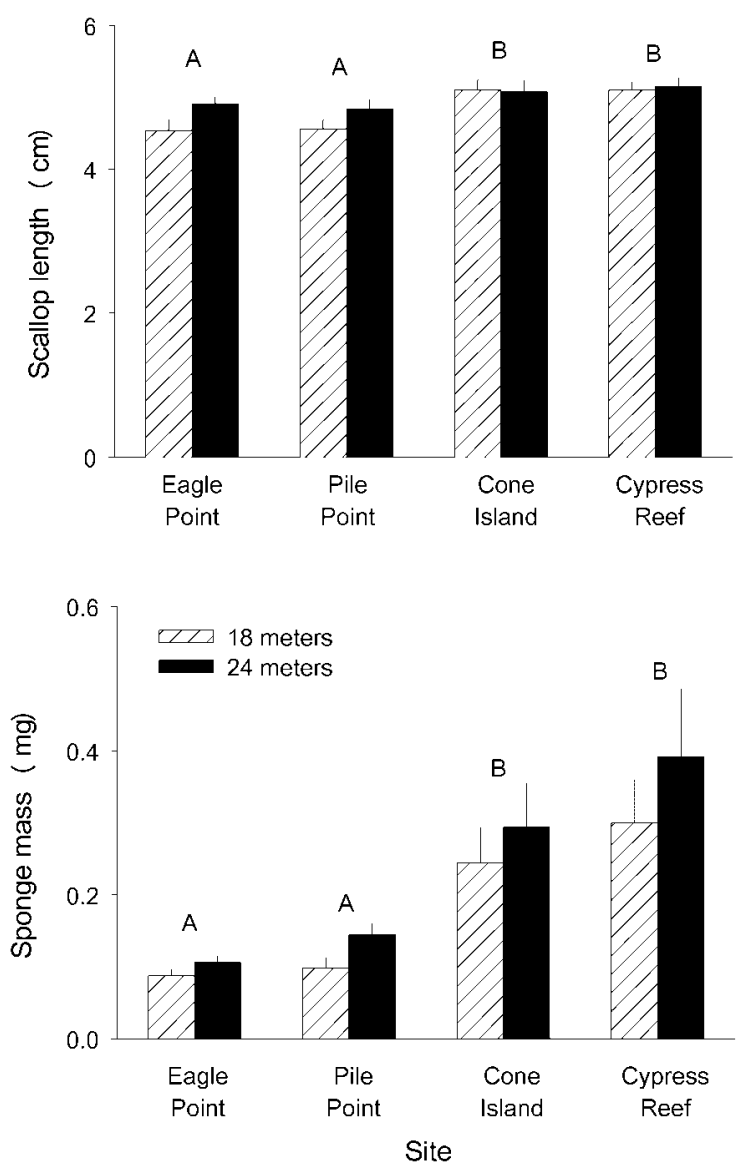

Figure 3. Lengths of Chlamys hastata (hinge to anterior end) and sponge biomass of samples collected from four study sites. Letters over the bars represent results of orthogonal contrasts. Bars with the same letter are not significantly different. Standard errors are shown.

The pattern in sponge sizes was similar (Table 2). Orthogonal contrasts again showed a significant difference between the exposed and the more protected inland sites $(P<0.01 ;$ Figure 3). Scallops from the sheltered sites held greater loads of epibiotic sponge cover even when the loads were corrected for the greater size of the scallops. There were again no differences between the two exposed $(P=0.22)$ or between the two protected sites $(P=0.68)$.

We found significant differences in sedimentation at the three study locations (the Eagle Point sediment collectors were lost). Site and depth were both significant but so was the sitexdepth interaction (Table 3). Figure 4 shows 
Table 2. Analysis of variance table for dry weight of epibiotic sponge on the valves of Chlamys hastata collected from four sites (Pile Point, Eagle Point, Cone Island and Rosario Strait) at 18 and $24 \mathrm{~m}$ depths. Data were log-transformed to homogenize variances prior to analysis.

\begin{tabular}{lrrrrr}
\hline Source & df & MS & $F$ & $P$ & Power \\
\hline Site & 3 & 1.24 & 8.50 & $<0.01$ & \\
Depth & 1 & 0.29 & 1.99 & 0.16 & 0.28 \\
Site $\times$ Depth & 3 & 0.04 & 0.28 & 0.83 & 0.10 \\
Error & 149 & 0.14 & & & \\
\hline
\end{tabular}

Total

157

Table 3. Analysis of variance table for dry weight of sediments collected from Pile Point, Cypress Island and Cone Island. Data were log-transformed to homogenize variances prior to analysis.

\begin{tabular}{lrrrc}
\hline Source & df & MS & $F$ & $P$ \\
\hline Site & 2 & 0.342 & 35.41 & $<0.01$ \\
Depth & 1 & 0.592 & 61.26 & $<0.01$ \\
SitexDepth & 2 & 0.282 & 29.20 & $<0.01$ \\
Error & 12 & 0.009 & & \\
\hline
\end{tabular}

Total 17

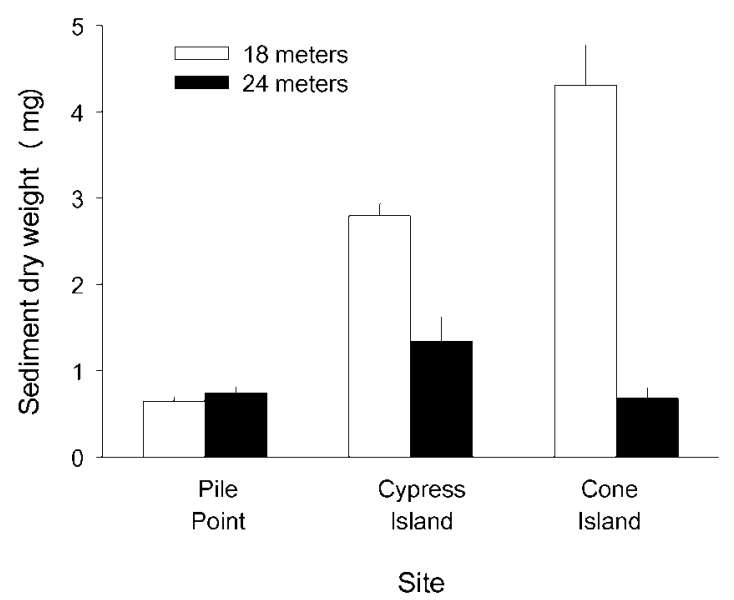

Figure 4. Dry weights of sediments collected from three study sites. No data were collected for the Eagle Point site. Standard errors are shown.

that the amount of sediment in the 24-m samples was similar at all three locations. However the 18-m collectors retained much more sediment at the two protected sites.

\section{Scallop behaviour}

With no external stimulation, all six sponge-encrusted scallops underwent regular cycles of clapping and swimming (Figure 5). Swimming or clapping occurred, on average, about once every 18 minutes.

\section{Sediment tolerance}

Both sponge species were sensitive to sediment accumulation. After five weeks, there were clear differences in the

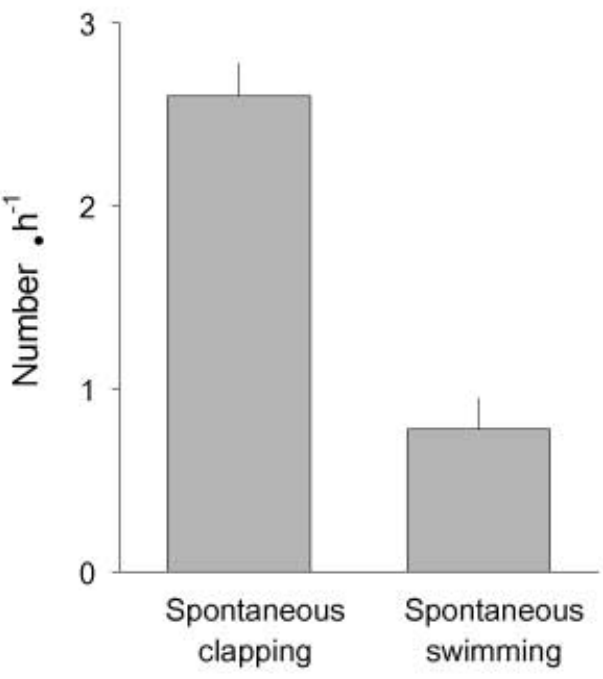

\section{Behaviour}

Figure 5. Spontaneous swimming/clapping behaviour by Chlamys hastata in the laboratory. Standard errors are shown.

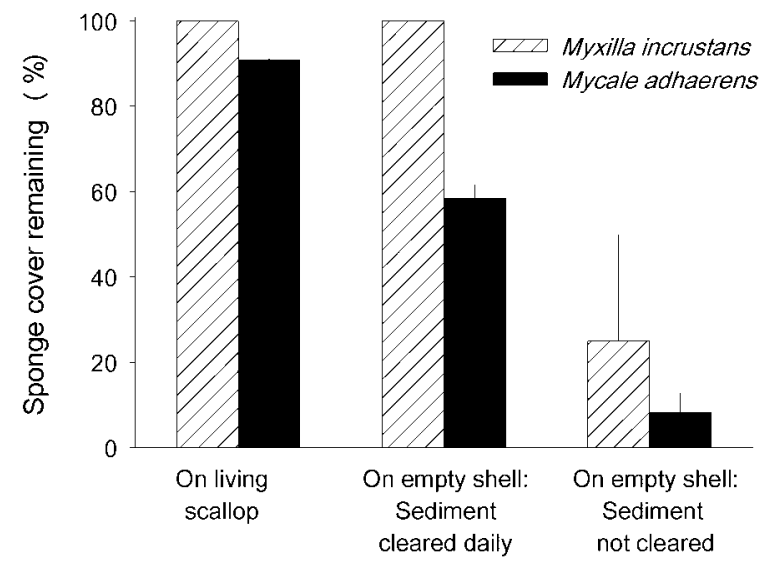

Figure 6. Survival of epibiotic sponges in the laboratory when they were: (1) on living Chlamys hastata; (2) on a single empty C. hastata valve that was cleaned daily by a gentle flow of water; or (3) on a single empty $C$. hastata valve that was left untreated for the duration of the experiment. Standard errors are shown.

Mycale adhaerens treatments $\left(F_{2,9}=116.9, P<0.01\right)$. Tukey's HSD tests showed that all three treatments were significantly different with the greatest sponge necrosis on uncleared, empty scallop shells (Figure 6). Daily sediment clearing decreased necrosis, but the sponges in the cleared treatment still experienced more than four times the tissue mortality of those on living scallops.

Due to the clear pattern in our results with Myxilla incrustans, we did not attempt any statistical analysis. Myxilla incrustans appeared to have some ability to remove sediment from its surface and showed no accumulation for the first four weeks of the experiment. In the fifth week, however, 3 of the 4 sponges on empty scallop shells could no longer slough sediments and were quickly overcome. Complete necrosis of these sponges occurred within days. Only one sponge in this treatment continued to slough sediment and experienced no visible necrosis. No necrosis was observed in sponge encrusting living scallops or on empty scallop shells from which we cleared sediment (Figure 6). 


\section{DISCUSSION}

In our laboratory experiments, Mycale adhaerens and Myxilla incrustans were both sensitive to sedimentation. Sponges on empty scallop shells quickly accumulated a smothering layer of silt, turning them grey and necrotic. Interestingly, though the two sponges live in the same habitat and have similar morphologies, they showed very different sediment tolerances. Mycale adhaerens was much more sensitive to sediment. This is in keeping with other studies that have shown sponges to have different silt tolerances (Rützler et al., 2000). It is not clear how Myxilla incrustans sloughed the silt, but it was able to do so for several weeks.

In all cases, sponges on live scallops showed better survival. Our experiments demonstrated that scallops effectively remove deposited sediments from the surfaces of their encrusting sponges. Presumably this occurred through the clapping and swimming of the scallops that (1) physically dislodged sediment and (2) changed the position of the scallop so that it was not always in a horizontal orientation where sediment would accumulate most rapidly.

Normal scallop behaviour was significantly more effective at preventing sponge death than was our manual clearing of sediments. In the manual treatment, we removed sediment once every 24 hours. In contrast, undisturbed scallops clapped their valves or swam, on average, 20 times in a 6-h period (Figure 5). If this activity level remains constant over an entire day, the clearing activity could occur up to 80 times per day. This would obviously be much more effective than the once-a-day treatment we administered.

We do not know why Chlamys hastata spontaneously clapped so often. It may simply be a mechanism to purge faeces and pseudofaeces from the mantle cavity. If that is the case, clapping frequency should increase with sediment load, again favouring survival of the sponge even under high sediment conditions.

The spontaneous swimming of $C$. hastata may be an attempt, on the scallop's part, to position itself in areas of higher flow where feeding conditions are better (Wildish et al., 1987). Once the scallop has found such a location, swimming frequency may drop. Such a flow environment would likely benefit the sponge by bringing in food and preventing sediment deposition (e.g. Ginn et al., 2000).

Based on our laboratory results, we might predict that epibiotic sponges would do better in the exposed sites on the west side of San Juan Island (Figure 1). Dry sediment weights there were five times lower than they were at Cone Island (Figure 4). It should be noted that our sediment samples were taken during the winter when turbidity in the Puget Sound is generally lowest. We expect that differences between inshore and exposed sites will be magnified during other seasons of the year as inshore sites are impacted by riverine input, runoff and blooms. This was verified by Secchi disk readings we took at all sites on two dates in March. Light attenuation coefficients (k) averaged only 0.062 at the exposed San Juan sites; attenuation was much greater at the Cone Island and Cypress Reef sites (average $\mathrm{k}=0.109$ ).

Data obtained from field surveys did not support the hypothesis that sponges would do better in low-sedimentation sites. Sponges seemed to do best in the sites with the highest turbidity (Cone Island and Cypress Reef; Figure 3). The answer to this discrepancy may lie in the difference in food availability at the sites. Sponges feed on very small plankton, detritus, and bacteria. They also assimilate dissolved organic carbon (Wilkinson \& Garrone, 1980). Water-borne sediments in our local waters carry a high organic fraction (personal observation). It may follow, therefore, that food availability is greater in the high turbidity sites. Cahalan et al. (1989) found that growth rates of the scallop Argopecten irradians were strongly affected by food concentrations. If the sediments at the Cone Island and Cypress Reef sites do carry a large organic fraction, we would predict larger scallops at those sites despite (or perhaps because of) the heavy sedimentation. This is, in fact, the pattern we observed (Figure 3). Turbid, nearshore sites in the local waters may, therefore, be an ideal habitat for sponge feeding if the obstacle of sediment accumulation can be overcome. It appears that living on the surface of a swimming scallop may be the means to accomplish that purpose.

The association between Chlamys spp., Mycale adhaerens and Myxilla incrustans is very strong. While both sponges can occasionally be found on other substrates, they are almost exclusively found on scallops. In fact, their location on mobile scallops is a principal feature used for their identification (Kozloff, 1996). During the surveying of our study sites, we looked for patches of either Mycale adhaerens or Myxilla incrustans growing anywhere besides on the valves of a Chlamys spp. A single thin patch of Mycale adhaerens was found encrusting a large barnacle at Cone Island. Sponges of both species were found only on scallops at the remaining three sites though open space was abundant.

The scallop/sponge association can commence only when a sponge larva chooses to settle on the scallop valve. For this to happen regularly, when there is abundant available space on other substrata, there must be a strong selective advantage for the sponge. Our data suggest that Mycale adhaerens and Myxilla incrustans receive significant benefits from living on scallop valves. The clapping and swimming of the scallops help the sponges shed sediments that would otherwise smother and kill them. In addition, scallop behaviour may position the sponges in regions of the most favourable feeding currents. Living on the scallops may allow the sponges to inhabit, and strongly benefit from, areas of high food concentrations where they achieve increased growth despite heavy sediment loads. This is a possibility that merits further study.

We thank Dr David Schneider for his invaluable support, time and knowledge. This project would have been impossible without the help of Dr Arlen Burns and Analiese Burns. We appreciate their hard work and support in SCUBA diving and collection. We thank Gene McKeen, Nate Schwark, Jason Whitaker and Dr Jody Stecker for advice and logistical support. Dr Steven Sulkin provided research space and support at the Shannon Point Marine Center.

\section{REFERENCES}

Bakus, G.J., 1967. Sedimentation and benthic invertebrates of Fanning Island, central Pacific. Marine Geology, 6, 45-51.

Bloom, S.A., 1975. The motile escape response of a sessile prey: a sponge-scallop mutualism. Journal of Experimental Marine Biology and Ecology, 17, 311-321. 
Berkman, A.P., 1994. Epizoic zonation on growing scallop shells in McMurdo Sound, Antarctica. Fournal of Experimental Marine Biology and Ecology, 179, 49-67.

Cahalan, J.A., Siddall, S.E. \& Luckenbach, M.W., 1989. Effects of flow velocity, food concentration and particle flux on growth rates of juvenile bay scallops Argopecten irradians. Fournal of Experimental Marine Biology and Ecology, 129, 45-60.

Chernoff, H., 1987. Factors affecting mortality of the scallop Chlamys asperrima (Lamarck) and its epizoic sponges in South Australian waters. Fournal of Experimental Marine Biology and Ecology, 109, 155-171.

Forester, A.J., 1979. The association between the sponge Halichondria panicea (Pallas) and the scallop Chlamys varia (L.): a commensal-protective mutualism. Fournal of Experimental Marine Biology and Ecology, 36, 1-10.

Gerrodette, T. \& Flechsig, A.O., 1979. Sediment-induced reduction in the pumping rate of the tropical sponge Verongia lacunosa. Marine Biology, 55, 103-110.

Ginn, B.K., Logan, A. \& Thomas, M.L., 2000. Sponge ecology on sublittoral hard substrates in a high current velocity area. Estuarine, Coastal and Shelf Science, 50, 403-414.

Kozloff, E.N., 1996. Marine invertebrates of the Pacific Northwest. Seattle: University of Washington Press.
Mauzey, K.P., Birkland, C. \& Dayton, P.K., 1968. Feeding behavior of asteroids and escape responses of their prey in the Puget Sound region. Ecology, 49, 603-619.

Rodenhous, I. \& Gueberlet, J.E., 1946. The morphology and behavior of the cushion star Pteraster tesselatus. University of Washington Publications in Biology, 12, 21-48.

Rützler, K., Diaz, M.C., Van Soest, R.W.M., Zea, S., Smith, K.P., Alvarez, B. \& Wulff, J., 2000. Diversity of sponge fauna in mangrove ponds, Pelican Cays, Belize. Atoll Research Bulletin, 476, 231-248.

Ward, M.A. \& Thorpe, J.P., 1991. Distribution of encrusting bryozoans and other epifauna on the subtidal bivalve Chlamys opercularis. Marine Biology, 110, 253-259.

Wildish, D.J., Kristmanson, D.D., Hoar, R.L., deCoste, A.M., McCormick, S.D. \& White, A.W., 1987. Giant scallop feeding and response to flow. Fournal of Experimental Marine Biology and Ecology, 113, 207-213.

Wilkinson, G.R. \& Garrone, R., 1980. Nutrition of marine sponges. Involvement of symbiotic bacteria in the uptake of dissolved carbon. In Nutrition in the lower Metazoa (ed. D.C. Smith and Y. Tiffon), pp. 157-161. Oxford: Pergamon Press.

Submitted 19 March 2002. Accepted 19 August 2002. 